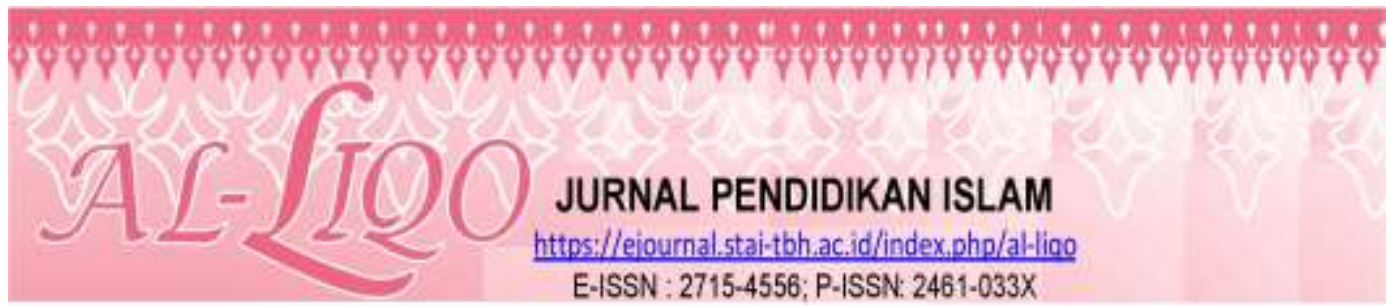

\title{
PEMBERDAYAAN ETIKA PANCASILA DALAM KONTEKS KEHIDUPAN KAMPUS
}

\author{
Deddy Yusuf Yudhyarta ${ }^{1)}$ \\ ${ }^{1}$ Dosen Tetap Program Studi Pendidikan Agama Islam STAI Auliaurrasyidin Tembilahan \\ Kabupaten Indragiri Hilir Propinsi Riau. Email : deddy.yusuf@ stai-tbh.ac.id
}

\begin{abstract}
Abstrak
Salah satu fungsi pendidikan adalah membangun karakter bangsa yang harus tetap dipertahankan. Begitu pula perlu dikembangkan nilai-nilai yang dikategorikan high-trust seperti Etika Pancasila menjadi fundamental bangsa dalam rangka penguatan integritas para penyelenggara negara atau pejabat publik jelas perlu penguatan etika. Etika umumnya dipahami sebagai 'teori atau ilmu tentang praktik moral. Sedanglkan Etika Pancasila secara normatif dapat dijadikan sebagai suatu acuan atas tindakan baik, dan secara filosofis dapat dijadikan perspektif kajian atas nilai dan norma yang berkembang dalam masyarakat. Namun, sebagai suatu kesatuan nilai yang utuh, nilai-nilai tersebut memberikan ciri khusus pada ke-Indonesia-an. Pancasila sebagai dasar etika dalam kehidupan bermasyarakat, berbangsa, dan bernegara diberdayakan melalui kebebasan akademik untuk mendasari suatu sikap mental atau attitude. Kebebasan akademik adalah hak dan tanggung jawab seseorang akademisi. Hak dan tanggung jawab itu terkait pada moral akademik.
\end{abstract}

Kata Kunci : Etika Pancasila, Kehidupan Kampus

\section{PENDAHULUAN}

Masalah etika merupakan masalah yang makin mendapat perhatiancitacita reformasi untuk membangun Indonesia Baru.Inti dari cita-cita tersebut adalah sebuah masyarakat sipil demokratis, dan ditegakkannya hukum untuk supremasi keadilan, pemerintahan yang bersih dari $\mathrm{KKN}$, terwujudnya keteraturan sosial dan rasa aman dalam masyarakat yang menjamin kelancaran produktivitas warga masyarakat, dan kehidupan ekonomi yang mensejahterakan rakyat Indonesia. Bangunan Indonesia Baru dari hasil reformasi atau perombakan tatanan kehidupan Orde Baru adalah sebuah masyarakat multikultural Indonesia. dari puing-puing tatanan kehidupan Orde Baru yang bercorak masyarakat majemuk (plural society). Sehingga, corak masyarakat Indonesia yang bhinneka tunggal ikabukan lagi keanekaragaman suku-bangsa dan kebudayaannya tetapi 
keanekaragaman kebudayaan yang ada dalam masyarakat Indonesia. Acuan utama bagi terwujudnya masyarakat Indonesia yang multikultural adalah multikulturalisme, yaitu sebuah ideologi yang mengakui dan mengagungkan perbedaan dalam kesederajatan baik secara individual maupun secara kebudayaan ${ }^{1}$. Model multikulturalisme ini sebenarnya telah digunakan sebagai acuan oleh para pendiri bangsa Indonesia dalam mendesain apa yang dinamakan sebagai kebudayaan bangsa, sebagaimana yang terungkap dalam penjelasan Pasal 32 UUD 1945, yang berbunyi: "kebudayaan bangsa (Indonesia) adalah puncakpuncak kebudayaan di daerah". Dalam masyarakat kita sebenarnya terdapat banyak nilai budaya yang sering tumpang tindih dan berpadu dengan nilai dan ajaran agama seperti etos kerja yang tinggi untuk menjalankan tugas sebaik mungkin; disiplin dalam pelaksanaan pekerjaan dan tugas; jujur dalam pelaksanaan tugas; amanah dalam memegang setiap tanggung jawab; bertanggung jawab (akuntabel) dalam tugas; adil dalam menghadapi dan menyelesaikan berbagai masalah; malu melakukan kesalahan; dan patuh pada tatanan hukum, ketentuan dan ketertiban.

Nilai-nilai budaya dan agama yang kondusif dan suportif bagi penciptaan dan penguatan integritas para pejabat publik sayangnya belum 'membudaya' dalam kehidupan dan perilaku sehari-hari. Faktor penyebabnya cukup banyak, mulai dari 'keterbelahan pribadi' (split personality) pejabat publik bersangkutan yang dalam praktiknya memisahkan nilai budaya dan agama yang luhur dengan praktik kehidupan sehari-hari mereka.Faktor kedua, adanya dorongan gaya hidup materialistik dan hedonistik yang membuat pejabat publik tergoda melakukan pelanggaran integritas. Faktor ketiga, lemahnya penghormatan pada tatanan hukum. Faktor keempat, lemahnya penegakan hukum dari para penegak hukum; dan kelima, adanya permissivisme luas dari masyarakat terhadap pelanggaran norma etika, budaya dan agama yang dilakukan kalangan pejabat publik.

Pancasila sebagai dasar negara pada hakikatnya merupakan sumber dari segala norma, baik norma hukum, norma moral, maupun norma kenegaraan lainnya. Norma hukum adalah suatu sistem peraturan perundang-undangan yang berlaku di Indonesia. Dalam pengertian inilah maka Pancasila berkedudukan

${ }^{1}$ Fay 1996, Jary dan Jary 1991, Watson 2000 
sebagai sumber dari segala sumber hukum di negara Indonesia. Norma moral berkaitan dengan tingkah laku manusia sebagai manusia untuk mengukur baik atau buruknya sebagai manusia. Dalam kapasitas inilah nilai-nilai Pancasila telah dijabarkan dalam norma-norma moralitas atau norma-norma etika sehingga Pancasila merupakan sistem etika dalam bermasyarakat, berbangsa dan bernegara.

\section{METODE PENELITIAN}

Jenis penelitian menggunakan pendekatan deskriptif kualitatif yang penulis gunakan adalah library research yaitu mengumpulkan buku-buku yang berkaitan dengan objek penelitian atau penelitian yang bersifat kepustakaan.

1. Sumber Data

Kajian yang penulis gunakan adalah penelitian perpustakaan murni, penulis akan menggunakan dua sumber, yaitu:

a. Sumber Primer

Sumber data yang berifat primer adalah buku rujukan awal dan utama dalam penelitian, sumber primer yang penulis gunakan adalah :

i. Aryaning A., Agus Riyanto dan Hendar Putranto. Pendidikan Kewarganegaraan (Civics). (Tangerang:UMN Press, 2012)

ii. Fudyartanto, Etika, (Yogyakarta: Warawidyani,1974), Cetakan Keempat.

iii. Kaelan, Pendidikan Pancasila, Edisi Reformasi. Yogyakarta: Penerbit Paradigma, 2004)

iv. Magnis-Suseno, F. Etika Politik: Prinsip-prinsip Moral Dasar Kenegaraan Modern. Jakarta: PT Gramedia.

v. Syarbaini,S., Rusdiyanta, Fatkhuri, Pendidikan Kewarganegaraan Implemen-tasi Karakter Bangsa.Jakarta: HartomoMedia Pustaka, 2012)

b. Sumber Sekunder

Sumber sekunder adalah hasil pengumpulan yang dilakukan oleh orang lain dengan maksud tertentu dan mempunyai kategori atau klasifikasi menurut keperluan masing-masing dan kegunaan bagi peneliti masing- 
masing. ${ }^{2}$ Dalam hal ini Sumber data yang berifat sekunder adalah buku rujukan pendukung dalam penelitian, sumber sekunder yang penulis gunakan adalah :

i. Hadiwijono,H, Sari Sejarah Filsafat Barat 2, (Yogyakarta: Kanisius, 1990) Cetakan Keempat.

ii. Keraf, Sonny, Etika Lingkungan, Penerbit Buku Kompas, Jakarta, 2002)

iii. Kohleberg, Lawrence, Tahap-tahap Perkembangan Moral, (Kanisius, Yogyakarta, 1995)

iv. Kuswanjono, Arqom, "Etika Keanekaragaman Hayati”, Makalah Seminar Nasional "Bioetika Lingkungan", Training Center Universitas Islam Negeri Sunan Kalijaga, Yogyakarta, 21 Juli 2008.

v. Magnis-Suseno, F. Etika Dasar :Masalah-masalah Pokok Filsafat Moral.Yogyakarta: Kanisius, 1987)

vi. Magnis-Suseno, F. Etika Politik: Prinsip-prinsip Moral Dasar Kenegaraan Modern. Jakarta: PT Gramedia.

vii. Mubarak, Zakky, Mata Kuliah Pengembangan Kepribadian Terintegrasi, Buku Ajar II, Manusia, Akhlak, Budi Pekerti dan Masyarakat. Depok, Lembaga Penerbit FE UI, 2008)

viii. Syarbaini,S. Pendidikan Pancasila di Perguruan Tinggi. Jakarta:

Ghalia Indonesia, 2003)

2. Teknik Pengumpulan Data

Teknik pengumpulan data adalah cara-cara yang digunakan oleh peneliti untuk mengumpulkan data. ${ }^{3}$ Pengumpulan data dalam penelitian ini adalah dengan cara dokumentasi. Dokumentasi adalah "ditujukan untuk memperoleh data langsung dari tempat penelitian, meliputi buku-

${ }^{2}$ S. Nasotion, Metode Research Penelitian Ilmiah, (Jakarta: Bumi Aksara, 2002), Cet. 5,

3 Riduwan, Skala Pengukuran Variabel-Variabel Penelitian, (Bandung: Alfabeta, 2013), Cet. Ke-10, h. 24 
buku yang relevan, peraturan-peraturan, laporan kegiatan, foto-foto, fim, dokumenter, data yang relevan penelitian". ${ }^{4}$

3. Teknik Analisa Data

Teknik analisa data adalah cara penghitungan untuk menjawab rumusan masalah dan pengujian hipotesis yang diajukan. ${ }^{5}$ Hipotesis adalah jawaban sementara yang harus di uji kebenarannya. Namun, penelitian yang penulis gunakan dengan kajian pustaka (library research) ini, maka penulis menggunakan tekhnik analisa data kajian isi (countent analysis).

Kajian ini adalah kajian yang menanfaatkan buku atau dokumen untuk menarik kesimpulan, baik kajian isi yang bersifat deduktif maupun kajian isi yang bersifat induktif. ${ }^{6}$ Pada kajian ini peneliti terlebih dahulu mengadakan survei data untuk memperoleh informasi dari penelitian terdahulu terhadap pengerjaan tanpa memperdulikan apakah data itu primer atau sekunder, di lapangan atau dilaboratorium. Kemudian, menelusuri leteratur yang ada serta mentelaahnya secara tekun. Setelah itu, peneliti mengungkapkan buah pikiran secara kritis dan analistis. ${ }^{7}$

\section{PEMBAHASAN}

Etika merupakan suatu pemikiran kritis yang mendasar tentang ajaranajaran dan pandangan-pandangan moral. Etika adalah suatu ilmu yang membahas tentang bagaimana dan mengapa kita mengikuti suatu ajaran moral terentu, atau bagaimana kita harus mengambil sikap yang bertanggung jawab berhadapan dengan berbagai ajaran moral ${ }^{8}$. Etika termasuk kelompok filsafat praktis dan dibagi menjadi etika khusus yaitu etika yang membahas prinsip dalam berbagai aspek kehidupan manusia sedangkan etika umum yaitu mempertanyakan prinsip-

${ }^{4}$ Ibid., h. 31

5 Riduan, Belajar Mudah Penelitian Untuk Guru, Karyawan Dan Peneliti Pemula, (Bandung: Alfabeta, 2015). h. 12

${ }^{6}$ Lexy J. Moleong, Metodologi Penelitian Kualitatif (Bandung:Remaja Rosdakarya, 2013), Cet. 31, h. 220

${ }^{7}$ Moh. Nazir, Metode Penelitian, (Bogor Selatan: Ghalia Indonesia, 2005), h. 93

${ }^{8}$ Suseno, 1987 
prinsip yang berlaku bagi setiap tindakan manusia ${ }^{9}$. Menurut Kattsoff, 1986 etika lebih banyak bersangkutan dengan prinsip-prinsip dasar pembenaran dalam hubungan dengan tingkah laku manusia, dan juga berkaitan dengan dasar filosofis dalam hubungan dengan tingkah laku manusia.

Secara etimologis, etika berasal daribahasa Yunani, ethos, yang artinya watak kesusilaan atau adat. Sedangkan bentuk jamaknyata etha" artinya adat kebiasaan. Istilah etika berarti ilmu tentang apa yang bisa dilakukan, atau ilmu tentang adat kebiasaan ${ }^{10}$. Istilah ini identik dengan moral yang berasal dari bahasa Latin, mos yang jamaknya mores, yang juga berarti adat atau cara hidup. Meskipun kata etika dan moral memiliki kesamaan arti, dalam pemakaian seharihari dua kata ini digunakan secara berbeda. Moral atau moralitas digunakan untuk perbuatan yang sedang dinilai, sedangkan etika digunakan untuk mengkaji sistem nilai yang ada ${ }^{11}$. Dalam bahasa Arab, padanan kata etika adalah akhlak yang merupakan kata jamak khuluk yang berarti perangai, tingkah laku atau tabiat $^{12}$.

Objek etika manurut Franz Magnis-Suseno ${ }^{13}$ adalah pernyataan moral. Apabila diperiksa segala macam moral, pada dasarnya hanya ada dua macam, yaitu, pernyataan tentang tindakan manusia dan pernyataan tentang manusia sendiri atau tentang unsur-unsur kepribadian manusia seperti motif-motif, dan watak. Ada himpunan pernyataan ketiga yang tidak bersifat moral, tetapi penting dalam rangka pernyataan tentang tindakan. Berdasarkan pendapat Franz MagnisSuseno tersebut membuat skema sebagai berikut ${ }^{14}$ :

${ }^{9}$ Suseno, 1987

${ }^{10}$ Bertens, 2007:4

${ }^{11}$ Zubair, 1987: 13

${ }^{12}$ Zakky, 2008: 20.)

${ }^{13}$ dalamZubair, 1987:18

${ }^{14}$ dalamZubair,1987:18 


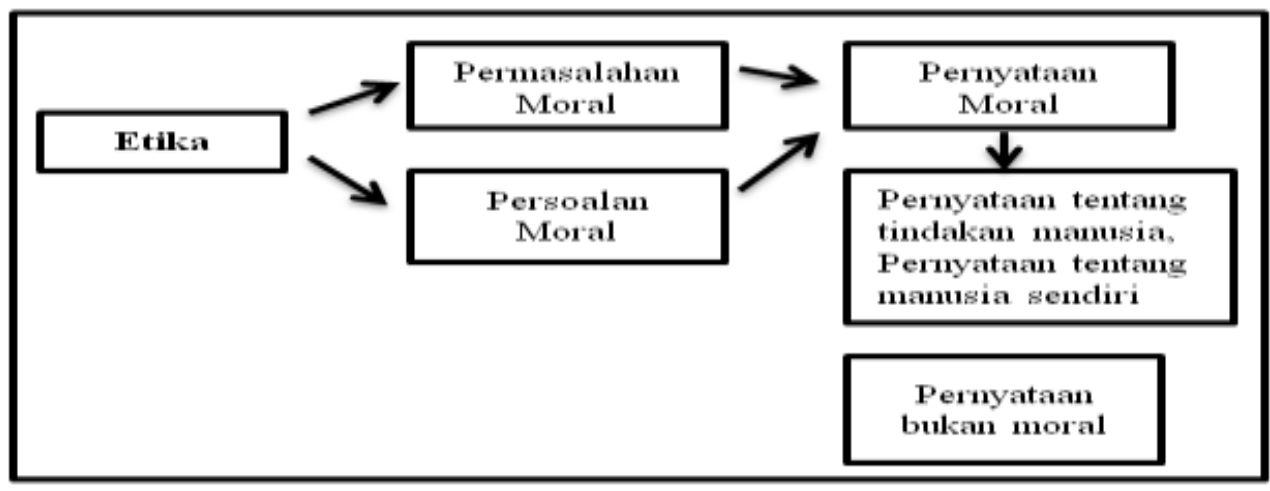

Berdasarkan skema tersebut dapat di rincikan sebagai berikut ${ }^{15}$ :

a. Dalam beberapa pernyataan kita mengatakan bahwa suatu tindakan tertentu sesuai atau tidak sesuai dengan norma-norma moral dan oleh karena itu adalah betul, salah, dan atau wajib. Contoh: "Engkau seharusnya mengembalikan uang itu". "Mencuri itu salah" "Perintah jahat tidak boleh ditaati" Ketiganya disebut sebagai pernyataan kewajiban.

b. Orang, kelompok orang dan unsur-unsur kepribadian (motif, watak, dan sebagainya) kita nilai sebagai baik, buruk, jahat, mengagumkan, suci, memalukan, bertanggung jawab, pantas ditegur, disebut sebagai pernyataan penilaian moral.

c. Himpunan pernyataan ketiga yang harus diperhatikan adalah penilaian bukan moral. Contoh: Mangga itu enak, Anak itu sehat. Mobil itu baik, Kertas ini jelek, dan sebagainya.

Perbedaan penting mengenai beberapa pernyataan di atas :

a. Pernyataan kewajiban tidak mengenal tingkatan. Wajib atau tidak wajib, betul atau salah tidak ada tengahnya.

b. Penilaian moral dan bukan moral mengenal tingkatan. Rasa dari sebuah mangga dapat agak enak atau enak sekali. Watak bersifat amat jahat atau agak jahat; dan lain sebagainya.

Sedangkan Nilai yang dalam bahasa Inggris disebut "value", menurut Djahiri (1999), dapat diartikan sebagai harga, makna, isi dan pesan, semangat, atau jiwa yang tersurat dan tersirat dalam fakta, konsep, dan teori, sehingga bermakna secara fungsional. Jadi nilai itu pada hakikatnya adalah sifat atau

\section{Zubair(1987:19}


kualitas yangmelekat pada suatu objek, bukan objek itu sendiri ${ }^{16}$. Di dalam nilai itu sendiri terkandung cita-cita, harapan-harapan, dan keharusan. Oleh karena itu, apabila kita berbicara tentang nilai, berarti berbicara tentang das solen bukan das sein. Artinya bahwa das solen itu harus menjelma menjadi das sein, yang ideal menjadi real, yang bermakna normatif harus direalisasikan dalam perbuatan sehari-hari yang merupakan fakta.

Menilai berarti, suatu kegiatan manusia untuk menghubungkan sesuatu dengan sesuatu yang lain, kemudian untuk selanjutnya diambil keputusan. Keputusan itu merupakan keputusan nilai yang dapat menyatakan berguna atau tidak berguna, benar atau tidak benar, baik atau tidak baik, indah atau tidak indah.Pendidikan nilai adalah pendidikan yang mensosialisasi kan dan menginternalisasikan nilai-nilai dalam diri peserta didik. Pendidikan Pancasila sebagai pendidikan nilai, berusaha mensosialisasikan dan menginternalisasikan nilai-nilai budaya bangsa dan nilai-nilai filsafat bangsa yaitu Pancasila. Pelaksanaannya selain melalui taksonomi yang dikembangkan oleh Bloom, juga bisa menggunakan jenjang afektif yaitu menerima nilai (receiving), menanggapi nilai/penanggapan nilai (responding), penghargaan nilai (valuing), pengorganisasian nilai (organization), karakterisasi nilai (characterization).

Nilai Pancasila yang digali dari bumi Indonesia sendiri merupakan pandangan hidup/panutan hidup bangsa Indonesia. Kemudian, ditingkatkan kembali menjadi Dasar Negara yang secara yuridis formal ditetapkan pada tanggal 18 Agustus 1945, yaitu sehari setelah Indonesia merdeka. Secara spesifik, nilai Pancasila telah tercermin dalam norma seperti norma agama, kesusilaan, kesopanan, kebiasaan, serta norma hukum. Dengan demikian, nilai Pancasila secara individu hendaknya dimaknai sebagai cermin perilaku hidup sehari-hari yang terwujud dalam cara bersikap dan dalam cara bertindak. Misalnya, nilai contoh gotong-royong.

Notonagoro juga berpendapat bahwa nilai-nilai Pancasila tergolong nilainilai kerohanian, tetapi nilai-nilai kerohanian yang mengakui adanya nilai material dan nilai vital. Dengan demikian, nilai-nilai lain secara lengkap dan harmonis,baik nilai material, nilai vital, nilai kebenaran, nilai keindahan atau nilai estetis, nilai

${ }^{16}$ Kaelan, 2003: 87 
kebaikan atau nilai moral, maupun nilai kesucian yang sistematika- hirarkhis, yang dimulai dari sila Ketuhanan Yang Maha Esa sebagai 'dasar' sampai dengan sila keadilan sosial bagi seluruh rakyat Indonesia sebagai 'tujuan'.

Norma adalah tolok ukur/alat untuk mengukur benar salahnya suatu sikap dan tindakan manusia. Norma juga bisa diartikan sebagai aturan yang berisi rambu-rambu yang menggambarkan ukuran tertentu, yang di dalamnya terkandung nilai benar/salah ${ }^{17}$ Dalam bahasa Inggris,norma diartikan sebagai standar. Di samping itu, norma juga bisa diartikan kaidah atau petunjuk hidup yang digunakan untuk mengatur perilaku manusia dalam kehidupan bermasyarakat maupun bernegara. Jika norma dipahami sebagai standar (ukuran) perilaku manusia, yang dapat dijadikan "alat" untuk menghakimi (justifikasi) suatu perilaku manusia (benar atau salah), maka dalam realitas kehidupan seharihari terdapat paling tidak 5 norma, yaitu (1) norma agama, (2) norma hukum, (3) norma moral atau susila, (4) norma kebiasaan, dan (5) norma kesopanan. Norma agama adalah tolok ukur benar salah yang mendasarkan diri pada ajaran-ajaran agama. Dalam agama-agama selalu ada perintah dan larangan. Ada halal haram lengkap dengan sanksi-sanksi bagi pelanggar ajaranajaran agama. Norma agama itu tentunya berlaku bagi pemeluknya karena beragama itu dasarnya adalah keyakinan. Norma hukum adalah norma yang dituntut dengan tegas oleh masyarakat dan dianggap perlu demi kemaslahatan dan kesejahteraan umum.

Norma moral atau susila adalah tolok ukur yang dipakai masyarakat untuk mengukur kebaikan seseorang. Tolok ukur penilaiannya adalah ukuran baik dan buruk berdasarkan nilai-nilai yang dijunjung tinggi atau yang dianggap rendah masyarakat tempat manusia yang bersangkutan itu berada. Dengan norma moral itu, seseorang benar-benar dinilai perilakunya. Norma kebiasaan adalah tolok ukur perilaku manusia yang berdasarkan pada hal-hal yang telah berlangsung dalam masyarakat sebagai suatu adat istiadat atau kebiasaan sehari-hari.

Pelanggaran norma biasanya mendapatkan sanksi, tetapi tidak selalu berupa hukuman di pengadilan atau penjara. Sanksi dari norma agama lebih ditentukan oleh Tuhan. Oleh karena itu, hukumannya berupa siksaan di akhirat, atau di dunia atas kehendak Tuhan. Sanksi pelanggaran/ penyimpangan norma

\footnotetext{
${ }^{17}$ Margono, 2001:67
} 
kesusilaan adalah moral yang biasanya berupa gunjingan dari lingkungannya. Penyimpangan norma kesopanan dan norma kebiasaan, seperti sopan santun dan etika yang berlaku di lingkungannya, juga mendapat sanksi moral dari masyarakat, misalnya berupa gunjingan atau cemoohan. Begitu pula norma hukum, biasanya berupa aturan-aturan atau undang-undang yang berlaku di masyarakat dan disepakati bersama.

Norma adalah aturan-aturan dan ketentuan-ketentuan yang mengikat warga masyarakat atau kelompok tertentu dan menjadi panduan, tatanan, padanan dan pengendali sikap dan tingkah laku manusia. Agar manusia mempunyai harga, moralmengandung integritas dan martabat pribadi manusia. Sedangkan derajat kepribadian sangat ditentukan oleh moralitas yang dimilikinya, maka makna moral yang terkandung dalam kepribadian seseorang tercermin dari sikap dan tingkah lakunya. Oleh karena itu, norma sebagai penuntun, panduan atau pengendali sikap dan tingkah laku manusia. Pada mulanya norma berarti alat tukang batu atau tukang kayu yang berupa segitiga. Dalam perkembangannya norma berarti ukuran, garis pengarah, atau aturan, dan kaidah bagi pertimbangan serta penilaian. Nilai yang menjadi milik bersama didalam satu masyarakat dan telah tertanam dengan emosiyang mendalamakan menjadi norma yang disepakati bersama.Segala hal yang kita beri nilai baik, cantik atau berguna akan kita usahakan supaya diwujudkan kembali di dalam perbuatan kita. Sebagai hasil usaha itu maka timbul ukuran perbuatan atau norma tindakan. Norma yang diterima oleh anggota masyarakat selalu mengandung sanksi dan pahala.

1. Tidak dilakukan sesuai norma hukuman; celaan dan lain sebagainya.

2. Dilakukansesuaidengannormapujian; balas jasa dan sebagainya.Jadi skemanya sebagai berikut

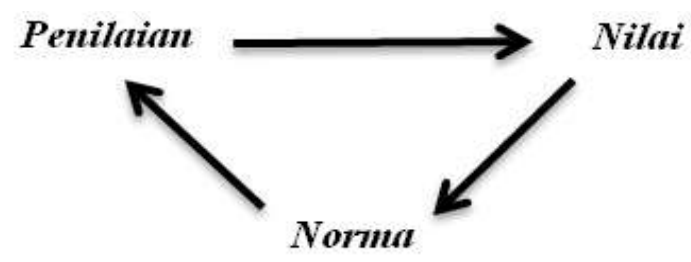

Ada banyak macam norma. Ada norma-norma khusus, yaitu norma yang hanya berlaku dalam bidang dan situasi yang khusus, misalnya bola tidak boleh disentuh oleh tangan, hanya berlaku kalau dan sewaktu kita main sepak bola dan 
kita bukan kiper. Agar nilai menjadi lebih berguna dalam menuntun sikap dan tingkah laku manusia, maka ia perlu lebih dikonkretkan lagi serta diformulasikan menjadi lebih objektif sehingga memudahkan manusia untuk menjabarkannya dalam tingkah laku.Wujud yang lebih konkret dari nilai adalah norma. Terdapat berbagai macam norma. Dari berbagai macam norma tersebut norma hukumlah yang paling kuat keberlakuannya, karena dapat dipaksakan oleh kekuatan eksternal seperti penguasa atau penegak hukum. Selanjutnya nilai dan norma senantiasa berkaitan dengan moral dan etika. Istilah moral mengandung integritas dan martabat pribadi manusia. Derajat kepribadian seseorang amat ditentukan oleh moralitas yang dimilikinya. Makna moral yang terkandung dalam kepribadian seseorang itu tercermin dari sikap dan tingkah lakunya. Dalam pengertian inilah maka kita memasuki wilayah norma sebagai penuntun sikap dan tingkah laku manusia ${ }^{18}$.

Moral berasal dari kata latin "mos" jamaknya "mores" yang berarti adat atau cara hidup. Etika dan moral mengandung makna yang sama, tetapi dalam penilaian sehari-hari ada sedikit perbedaan. Moral dan moralitas dipakai untuk perbuatan yang sedang dinilai. Sedangkan etika dipakai untuk pengkajian sistem nilai yang ada. Magnis-Suseno ${ }^{19}$ membedakan antara ajaran moral dengan etika. Ajaran moral adalah ajaran-ajaran, wejangan-wejangan, khotbah-khotbah, peraturan-peraturan lisan atau tertulis tentang bagaimana manusia seharusnya hidup dan bertindak agar ia menjadi manusia yang baik. Sumber langsung bagi ajaran moral adalah pelbagai orang dalam kedudukan yang berwenang, seperti orang tua dan guru, para pemuka masyarakat dan agama, juga tulisan para bijak. Etika bukan sumber tambahan bagi ajaran moral tetapi filsafat atau pemikiran kritis dan mendasar tentang ajaran dan pandangan moral. Etika adalah sebuah ilmu dan bukan sebuah ajaran. Jadi etika dan ajaran moral tidak berada di tingkat yang sama. Hal yang mengajarkan bagaimana kita seharusnya menjalani hidup bukanlah etika melainkan ajaran moral. Etika mau mengerti ajaran moral tertentu, atau bagaimana kita dapat mengambil sikap yang bertanggung jawab dalam menghadapi pelbagai ajaran moral. Moral merupakan patokan-patokan,

\footnotetext{
18 Kaelan,2004: 92-93

${ }^{19}$ Magnis-Suseno (1987: 14
} 
kumpulan peraturan lisan maupun tertulis tentang bagaimana manusia harus hidup dan bertindak agar mnejadi manusia yang lebih baik. Moral dengan etika hubungannya sangat erat, sebab etika suatu pemikiran kritis dan mendasar tetang ajaran-ajaran dan pandangan moral dan etika merupakan ilmu pengetahuan yang membahas prinsip-prinsip moralitas (Devos, 1987). Etika merupakan tingkah laku yang bersifat umum universal berwujud teori dan bermuara ke moral, sedangkan moral bersifat tindakan lokal, berwujud praktek dan berupa hasil buah dari etika. Dalam etika seseorang dapat memahami dan mengerti bahwa mengapa dan atas dasar apa manusia harus hidup menurut norma-norma tertentu, inilah kelebihan etika dibandingkan dengan moral. Kekurangan etika adalah tidak berwenang menentukan apa yang boleh dan tidak boleh dilakukan seseorang, sebab wewenang ini ada pada ajaran moral.

Pengertian moral, menurut Suseno (1998) adalah ukuran baik buruk seseorang, baik sebagai pribadi maupun sebagai warga masyarakat, dan warga negara. Sedangkan pendidikan moral adalah pendidikan untuk menjadikan anak manusia bermoral baik dan manusiawi. Sedangkan menurut Ouska dan Whellan (1997), moral adalah prinsip baik buruk yang ada dan melekat dalam diri individu atau seseorang. Walaupun moral itu berada di dalam diri individu, tetapi moral berada dalam suatu sistem yang berwujud aturan. Moral dan moralitas ada sedikit perbedaan, karena moral adalah prinsip baik buruk sedangkan moralitas merupakan kualitas pertimbangan baik buruk. Dengan demikian, hakekat dan makna moralitas bisa dilihat dari cara individu yang memiliki moral dalam mematuhi maupun menjalankan aturan. Ada beberapa pakar yang mengembangkan pembelajaran nilai moral, dengan tujuan membentuk watak atau karakterstik anak. Pakar-pakar tersebut di antaranya Newman, Simon, Howe, dan Lickona. Dari beberapa pakar tersebut, pendapat Lickona lebih cocok diterapkan untuk membentuk watak/ karakter anak. Pandangan Lickona (1992) tersebut dikenal dengan educating for character atau pendidikan karakter/watak untuk membangun karakter atau watak anak. Dalam hal ini, Lickona mengacu pada pemikiran filosof Michael Novak yang berpendapat bahwa watak atau karakter seseorang dibentuk melalui tiga aspek yaitu, moral knowing, moral feeling, dan moral behavior, yang saling berhubungan dan terkait. 
Lickona menggarisbawahi pemikiran Novak. Ia berpendapat bahwa pembentukan karakter atau watak anak dapat dilakukan melalui tiga kerangka pikir, yaitu konsep moral (moral knowing), sikap moral (moral feeling), dan perilaku moral (moral behavior). Dengan demikian, hasil pembentukan sikapkarakter anak pun dapat dilihat dari tiga aspek, yaitu konsep moral, sikap moral, dan perilaku moral. Lebih jelasnya silakan mencermati alur pikir Lickona ${ }^{20}$ di bawah ini.

Pemikiran Lickona ini diupayakan dapat digunakan untuk membentuk watak anak, agar dapat memiliki karakter demokrasi, sehingga standar kompetensi demokrasi tercapai. Oleh karena itu, materi tersebut harus menyentuh tiga aspek, yaitu konsep moral (moral knowing) mencakup kesadaran moral (moral awarness), pengetahuan nilai moral (knowing moral value), pandangan ke depan (perspective taking), penalaran moral (reasoning), pengambilan keputusan (decision making), dan pengetahuan diri (self knowledge), ${ }^{21}$

\section{Hubungan Nilai, Norma, dan Moral}

Nilai adalah kualitas dari sesuatu yang bermanfaat bagi kehidupan manusia, baik lahir maupun batin. Dalam kehidupan manusia, nilai dijadikan landasan, alasan, atau motivasi dalam bersikap dan bertingkah laku baik disadasari maupun tidak. Nilai berbeda dengan fakta, karena fakta dapat diobservasi melalui suatu verifikasi empiris, sedangkan nilai bersifat abstrak yang hanya dapat dipahami, dipikirkan, dimengerti dan dihayati oleh manusia. Nilai berkaitan dengan harapan, cita-cita, keinginan dan segala sesuatu pertimbangan internal (batiniah) manusia. Nilai dengan demikian, tidak bersifat konkret yaitu tidak dapat ditangkap dengan indra manusia, dan nilai dapat bersifat subjektif maupun objektif. Bersifat subjektif manakala nilai tersebut diberikan oleh subjek (dalam hal ini manusia sebagai pendukung pokok nilai) dan bersifat objektif jikalau nilai tersebut telah melekat padasesuatu terlepas dari penilaian manusia ${ }^{22}$.

Agar nilai tersebut menjadi lebih berguna dalam menuntun sikap dan tingkah laku manusia maka perlu lebih dikonretkan lagi serta diformulasikan

\footnotetext{
${ }^{20}$ Dalam Wahab dan Winataputra, 2005: 1.16

${ }^{21}$ Ruminiati, $2005: 24$

22 Kaelan, 2003: 92
} 
menjadi lebih objektif sehingga memudahkan manusia untuk menjabarkannya dalam tingkah laku secara konkret. Wujud konkret dari nilai tersebut adalah merupakan suatu norma. Terdapat berbagai norma, dan dari berbagai macam norma tersebut, norma hukumlah yang paling kuat berlakunya, karena dapat dipaksakan oleh suatu kekuasaan eksternal, misalnya penguasa ataupenegak hukum.

Selanjutnya, nilai dan norma senantiasa berkaitan dengan moral dan etika. Istilah moral mengandung intregritas dan martabat pribadi manusia. Derajat kepribadian seseorang sangat ditentukan oleh moralitas yang dimilikinya. Makna moral yang terkandung dalam kepribadian seseorang itu tercermin dari sikap dan tingkah lakunya. Dalam pengertian inilah, maka manusia memasuki wilayah norma sebagai penuntun sikap dan tingkah laku. Hubungan antara moral dan etika memang sangat erat sekali dan kadang kala keduanya disamakan begitu saja. Namun sebenarnya, kedua hal tersebut memiliki perbedaan. Moral merupakan suatu ajaran-ajaran ataupun wejangan-wejangan, patokan-patokan, kumpulan peraturan, baik lisan maupun tertulis bagi sikap dan tindakan agar menjadi manusia yang baik.

Di pihak lain, etika adalah suatu cabang filsafat yaitu suatu pemikiran kritis dan mendasar tentang ajaran-ajaran dan pandangan-pandangan moral tersebut $^{23}$. Atau juga sebagaimana dikemukakan oleh De Vos (1987), bahwa etika dapat diartikan sebagai ilmu pengetahuan tentang kesusilaan. Adapun yang dimaksud dengan kesusilaan identik dengan pengertian moral, sehingga etika pada hakekatnya adalahsebagai ilmu pengetahuan yang membahas tentang prinsipprinsip moralitas. Setiap orang memiliki moralitas, tetapi tidak demikian dengan etika. Tidak semua orang melakukan pemikiran secara kritis terhadap etika. Terdapat suatu kemungkinan bahwa seseorang mengikuti begitu saja pola-pola moralitas yang ada dalam suatu masyarakat tanpa perlu merefleksikannya secara kritis. Etika tidak berwenang menentukan yang boleh atau tidak boleh dilakukan oleh seseorang. Wewenang ini dipandang sebagai pihak-pihak yang memberikan ajaran moral. Hal inilah yang menjadi kekurangan dari etika jikalau dibandingkan dengan ajaran moral. Sekalipun demikian, dalam etika seseorang dapat dipahami

${ }^{23}$ Krammer, 1988 dalam Darmodiharjo 1996 
penyebab dan dasar manusia harus hidup berdasarkan norma-norma tertentu. Hal yang terakhir inilah merupakan kelebihan etika jikalau dibandingkan dengan moral. Hal itu dapat dianalogikan bahwa ajaran moral sebagai "buku petunjuk tentang memperlakukan sebuah mobil dengan baik", sedangkan etika memberikan pengertian tentang "struktur dan teknologi mobil itu sendiri".

\section{Nilai-nilai Pancasila sebagai Sumber Etika}

Sebagai dasar filsafat negara, Pancasila tidak hanya merupakan sumber bagi peraturan perundangan, melainkan juga sumber moralitas terutama dalam hubungannya dengan legitimasi kekuasaan, hukum serta berbagai kebijakan dalam pelaksanaan dan penyelenggaraan negara. Oleh karena itu negara seharusnya sesuai dengan nilai-nilai yang berasal dari Tuhan terutama hukum serta moral dalam kehidupan negara. Asas kemanusiaan seharusnya merupakan prinsip dasar moralitas dalam pelaksanaan dan penyelenggaraan negara.

Dalam pelaksanaan dan penyelenggaraan negara, etika politik menuntut agar kekuasaan dalam negara dijalankan sesuai dengan 1) Asas legalitas, yaitu dijalankan sesuai dengan hukum yang berlaku, 2) disahkan dan dijalankan secara demokratis, serta 3) dilaksanakan berdasarkan prinsip-prinsip moral (legitimasimoral) $^{24}$.

Legitimasi etis mempersoalkan keabsahan kekuasaan politik dari segi norma-norma moral. Legitimasi ini muncul dalam konteks bahwa setiap tindakan negara baik dari legislatif maupun eksekutif dapat dipertanyakan dari segi normanorma moral. Tujuannya agar kekuasaan dapat diarahkan pada kebijakan dan cara-cara yang sesuai dengan tuntutan-tuntutan kemanusiaan yang adil dan beradab. Selain itu, pelaksanaan dan penyelenggaraan negara harus berdasarkan legitimasi hukum yaitu prinsip ‘legalitas’. Negara Indonesia adalah negara hukum. Oleh karena itu 'keadilan' dalam hidup bersama (keadilan sosial) sebagaimana terkandung dalam sila $\mathrm{V}$ merupakan tujuan dalam kehidupan negara. Terkait dengan itu, dalam pelaksanaan dan penyelenggaraan negara, segala kebijakan, kekuasaan, kewenangan serta pembagiannya harus senantiasa berdasarkan pada hukum yang berlaku. Pelanggaran atas prinsip-prinsip keadilan dalam kehidupan

\footnotetext{
${ }^{24}$ Kaelan, 2004: 101
} 
kenegaraan akan menimbulkan ketidakseimbangan dalam keberlangsungan kehidupan negara.

\section{Pelaksanaan EtikaPancasila}

Menurut Aryaning Arya Kresna $\mathrm{dkk}^{25}$. ada beberapa cara yang mudah untuk memahami politik Pancasila, yang dapat dipakai untuk mengajukan kritik terhadap praktik Pancasila. Pertama mempertanyakan tingkatan dijalankannya prinsip moral "menjunjung tinggi harkat dan martabat manusia". Apakah sebuah tindakan yang dilakukan sebuah lembaga pemerintahan telah menjunjung tinggi harkat dan martabat manusia? Kedua, mempertanyakan tingkatan kesesuaian antara nilai obyektif dengan nilai intersubyektif. Apakah sebuah tindakan yang dilakukan lembaga pemerintahan yang berdasarkan prinsip nilai intersubjektif "keadilan" sesuai dengan nilai objektif "adil”?Aktualisasi Pancasila sebagai dasar etika tercermin dalam sila-silanya, yaitu:

1. Sila pertama: menghormati setiap orang atau warga negara atas berbagai kebebasannya dalam menganut agama dan kepercayaannya masing-masing, serta menjadikan ajaran-ajaran sebagai anutan untuk menuntun ataupun mengarahkan jalan hidupnya.

2. Sila kedua: menghormati setiap orang dan warga negara sebagai pribadi (personal) "utuh sebagai manusia", manusia sebagai subjek pendukung, penyangga, pengemban, serta pengelola hak-hak dasar kodrati yang merupakan suatu keutuhan dengan eksistensi dirinya secara bermartabat.

3. Sila ketiga: bersikap dan bertindak adil dalam mengatasi segmentasisegmentasi atau primordialisme sempit dengan jiwa dan semangat "Bhinneka Tunggal Ika"- "bersatu dalam perbedaan" dan "berbeda dalam persatuan".

4. Sila keempat: kebebasan, kemerdekaan, dan kebersamaan dimiliki dan dikembangkan dengan dasar musyawarah untuk mencapai kemufakatan secara jujur dan terbuka dalam menata berbagai aspek kehidupan.

5. Sila kelima: membina dan mengembangkan masyarakat yang berkeadilan sosial yang mencakup kesamaan derajat (equality) dan pemerataan (equity) bagi setiap orang atau setiap warga negara.

${ }^{25}$ Aryaning Arya Kresna dkk. (2012: 53-54 
Sila-sila dalam pancasila merupakan satu kesatuan integral dan integrative menjadikan dirinya sebagai sebagai referensi kritik sosial kritis, komprehensif, serta sekaligus evaluatif bagi etika dalam kehidupan bermasyarakat, berbangsa ataupun bernegara. Konsekuensi dan implikasinya ialah bahwa norma etis yang mencerminkan satu sila akan mendasari dan mengarahkan sila-sila lain. Etika Kehidupan Berbangsa (Tap MPR No 01/MPR/2001) meliputi: Tanda-tanda mundurnya pelaksanaan etika berbangsa terdiri dari: Konflik sosial berkepanjangan, Berkurangnya sopan santun dan budi luhur dalam kehidupan sosial, Melemahnya kejujuran dan sikap amanah, Pengabaian ketentuan hukum dan peraturan.

Faktor-faktor penyebab mundurnya pelaksanaan etika, Faktor internal :Lemahnya penghayatan dan pengamalan agama, Sentralisasi di masa lalu, Tidak berkembangnya pemahaman/penghargaan kebinekaan, Ketidakadilan ekonomi, Keteladanan tokoh/pemimpin yang kurang, Penegakan hukum yang tidak optimal, Keterbatasan budaya lokal merespon pengaruh dari luar, Meningkatnya prostitusi, media pornografi, perjudian dan narkoba. Sedangkankan Faktor Eksternal, meliputi: Pengaruh globalisasi, Intervensi kekuatan global dalam panutan kebijakan nasional.

Pokok-Pokok Etika Berbangsa terdiri dari; Etika sosial budaya, Etika politik pemerintahan, Etika ekonomi dan bisnis, Etika penegakan hukum, Etika keilmuan dan Etika lingkungan.

Good Governance Sebagai Etika Pemerintahan meliputi :Partisipasi, Aturan Hukum (rule of law), Transparansi, Daya tanggap (responsiveness), Berorientasi konsensus (Consensus Orientation), Berkeadilan (Equity), Akuntabilitas (Accountability), Bervisi strategis (Strategic vision), Efektifitas dan efisiensi dan Saling keterkaitan (interrelated). Strategi/pendekatan peningkatan etika: Pendekatan larangan (Don't Approach), Pendekatan Untung-rugi (CostBenefit Approach), Pendekatan sistem (System Approach), Pendekatan kerjakan (Do Approach).

Pemberdayaan Etika Pancasila dalam Konteks Kehidupan Akademiksebagai dasar etika dalam kehidupan bermasyarakat, berbangsa, dan bernegara diberdayakan melalui kebebasan akademik untuk mendasari suatu 
sikap mental atau attitude. Kebebasan akademik adalah hak dan tanggung jawab seseorang akademisi. Hak dan tanggung jawab itu terkait pada susila akademik, yaitu;

1. Curiosity, dalam arti terus menerus mempunyai keinginan untuk mengetahui hal-hal baru dalam perkembangan ilmu pengetahuan, tidak mengenal titik henti, yang berpengaruhi dengan sendirinya terhadap perkembangan etika;

2. Wawasan, luas dan mendalam, dalam arti bahwa nilai-nilai etika sebagai norma dasar bagi kehidupan suatu bangsa dalam kehidupan bermasyarakat dan bernegara tidak terlepas dari unsur-unsur budaya yang hidup dan berkembang dengan ciri-ciri khas yang membedakan bangsa itu dari bangsa lain;

3. Terbuka, dalam arti luas bahwa kebenaran ilmiah adalah sesuatu yang tentatif, bahwa kebenaran ilmiah bukanlah sesuatu yang hanya sekali ditentukan dan bukan sesuatu yang hanya sekali ditentukan dan bukan sesuatu yang tidak dapat diganggu gugat, yang implikasinya ialah bahwa pemahaman suatu norma etika bukan hanya tekstual, melainkan juga kontekstual untuk diberi makna baru sesuai dengan kondisi aktual yang berkembang dalam masyarakat;

4. Open mindedness, dalam arti rela dan rendah hati (modest) bersedia menerima kritik dari pihak lain terhadap pendirian atau sikap intelektualnya;

5. Jujur, dalam arti menyebutkan setiap sumber atau informasi yang diperoleh dari pihak lain dalam mendukung sikap atau pendapatnya; serta

6. Independen, dalam arti beranggungjawab atas sikap dan pendapatnya, bebas dari tekanan atau "kehendak yang dipesankan" oleh siapa pun dan dari mana pun.

\section{KESIMPULAN}

Pancasila sebagai suatu sistem filsafat pada hakikatnya merupakan nilai sehingga ia menjadi sumber dari segala penjabaran norma baik norma hukum, norma moral maupun norma kenegaraan lainnya. Etika Pancasila berkaitan dengan objek formal etika, dan obyek material politik yang meliputi legitimasi negara, hukum, kekuasaan serta penilaian kritis terhadap legitimasi-legitimasi 
tersebut.

Nilai-nilai Pancasila sebagai sumber etika yakni :Sebagai dasar filsafat negara, Pancasila tidak hanya merupakan sumber bagi peraturan perundangan, melainkan juga merupakan sumber moralitas terutama dalam hubungannya dengan legitimasi kekuasaan, hukum serta berbagai kebijakan dalam pelaksanaan dan penyelenggaraan negara. Secara moralitas kehidupan negara terutama hukum serta moral dalam kehidupan negara harus sesuai dengan nilai-nilai yang berasal dari Tuhan. Asas kemanusiaan seharusnya menjadi prinsip dasar moralitas dalam pelaksanaan dan penyelenggaraan negara. Dalam pelaksanaan dan penyelenggaraan negara, etika politik menuntut agar kekuasaan dalam negara dijalankan sesuai dengan: asas legalitas, disahkan dan dijalankan secara demokratis, serta dilaksanakan berdasarkan prinsip-prinsip moral.

Sila-sila Pancasila tersusun atas urut-urutan sistematis. Dalam politik negara seharusnya didasarkan pada prinsip kerakyatan (Sila IV). Adapun pengembangan, dan aktualisasi politik negara berdasarkan pada moralitas berturut-turut moral Ketuhanan (Sila I), moral kemanusiaan (Sila II), dan moral persatuan yaitu ikatan moralitas sebagai suatu bangsa (Sila III). Adapun aktualisasi dan pengembangan politik negara demi tercapainya keadilan dalam hidup bersama (Sila V). Jadi, pengembangan politik negara terutama dalam proses reformasi seharusnya mendasarkan diri, dan aktualisasinya pada moralitas sebagaimana tertuang dalam sila-sila Pancasila sehingga, sebagai konsekuensinya, praktek politik yang menghalalkan segala cara dengan memfitnah, memprovokasi, menghasut rakyat yang tidak berdosa untuk diadu domba, seharusnya segera diakhiri. Apabila hal diatas dapat terealisasikan dengan baik maka hak rakyat Indonesia dapat di jamin sesuai dengan UUD 1945 pasal 27 ayat (2) yang berbunyi: tiap-tiap warga Negara berhak atas pekerjaan dan penghidupan yang layak bagi kemanusiaan.

Aktualisasi etika, nilai budaya dan agama yang suportif bagi integritas pejabat publik memerlukan berbagai dukungan. Dalam prakteknya nilai-nilai tersebut tidak bisa berdiri sendiri, sebab mereka lebih merupakan himbauan moral daripada kewajiban yang mesti dilaksanakan lengkap dengan sanksi-sanksi hukumnya. Karena itu, aktualisasi nilai-nilai itu selain memerlukan sosialisasi dan 
pembudayaan terus menerus, juga meniscayakan dukungan penegakan hukum konsisten, yang memiliki kekuatan memaksa sehingga nilai-nilai tersebut benarbenar teraktualisasi dalam kehidupan pribadi, masyarakat dan negara bangsa.

Pengembangan integritas dan etika para pejabat publik dapat dilakukan melalui pendidikan sejak pendidikan dasar, menengah hingga pendidikan tinggi. Banyak nilai tersebut telah diajarkan melalui berbagai mata pelajaran/mata kuliah. Persoalannya, nilai-nilai tersebut lebih diajarkan secara kognitif daripada afektif dan psiko-motorik. Karena itu nilai-nilai itu menjadi sekadar pengetahuan yang bakal diujikan daripada dipraktikkan dalam kehidupan sehari-hari. Mengingat kenyataan ini, perlu pendekatan dan metode pembelajaran baru yang lebih memungkinkan terjadinya internalisasi dan aktualisasi nilai-nilai tersebut bagi peserta didik dalam kehidupan mereka.Oleh karena itu, pancasila harus dijadikan sebagai pandangan hidup bangsa Indonesia demi terciptanya masyarakat yang adil, makmur dan sejahtera dengan mengembangkan hubungan yang serasi, selaras, dan seimbang antara lingkungan Tuhan Yang Maha Esa, diri sendiri, manusia lain atau masyarakat maupun dengan Negara yakni Negara Kesatuan Republik Idonesia.

\section{DAFTAR PUSTAKA}

Aryaning A., Agus Riyanto dan Hendar Putranto. Pendidikan Kewarganegaraan (Civics). (Tangerang:UMN Press, 2012)

Fudyartanto, Etika, (Yogyakarta: Warawidyani,1974), Cetakan Keempat.

Hadiwijono,H, Sari Sejarah Filsafat Barat 2, (Yogyakarta: Kanisius, 1990) Cetakan Keempat.

Lexy J. Moleong, Metodologi Penelitian Kualitatif (Bandung:Remaja Rosdakarya, 2013), Cet. 31

Kaelan, Pendidikan Pancasila, Edisi Reformasi, (Yogyakarta: Penerbit Paradigma, 2004)

Keraf, Sonny, Etika Lingkungan, (Jakarta : Penerbit Buku Kompas, Jakarta, 2002)

Ketetapan MPR Pada Sidang Tahunan MPR 2002. (Jakarta: Sinar 
Grafika.Kresna)

Kohleberg, Lawrence, Tahap-tahap Perkembangan Moral, (Yogyakarta :Kanisius, 1995)

Kuswanjono, Arqom, "Etika K eanekaragaman Hayati", Makalah Seminar Nasional "Bioetika Lingkungan", Training Center Universitas Islam Negeri Sunan Kalijaga, Yogyakarta, 21 Juli 2008.

Moh. Nazir, Metode Penelitian, (Bogor Selatan: Ghalia Indonesia, 2005), h. 93

Magnis-Suseno, F. Etika Dasar :Masalah-masalah Pokok Filsafat Moral.Yogyakarta: Kanisius, 1987)

Magnis-Suseno, F. Etika Politik: Prinsip-prinsip Moral Dasar Kenegaraan Modern, (Jakarta: PT Gramedia)

Mubarak, Zakky, Mata Kuliah Pengembangan Kepribadian Terintegrasi, Buku Ajar II, Manusia, Akhlak, Budi Pekerti dan Masyarakat. Depok, Lembaga Penerbit FE UI, 2008)

Riduwan, Skala Pengukuran Variabel-Variabel Penelitian, (Bandung: Alfabeta, 2013), Cet. Ke-10

Riduan, Belajar Mudah Penelitian Untuk Guru, Karyawan Dan Peneliti Pemula, (Bandung: Alfabeta, 2015)

Sunoto, Bunga Rampai Filsafat. Yog- yakarta: Yayasan Pembinaan Fakultas Filsafat UGM, 1982)

Syarbaini,S., Pendidikan Pancasila di Perguruan Tinggi, (Jakarta: Ghalia Indonesia, 2003)

S. Nasotion, Metode Research Penelitian Ilmiah, (Jakarta: Bumi Aksara, 2002), Cet. 5

Syarbaini,S., Rusdiyanta, Fatkhuri, Pendidikan Kewarganegaraan Implemen-tasi Karakter Bangs, (Jakarta: HartomoMedia Pustaka, 2012)

Zubair, Achmad Charris, Kuliah Etika, Rajawali Pers, Jakarta, 1990) 